\title{
Overview of Malaysian Traditional Batik Authenticity
}

\author{
Rahman Rosman'1, Hanif Khairi1, Rafeah Legino, ${ }^{2}$ Faradiba Liana Naser ${ }^{1}$ \\ ${ }^{1}$ Faculty of Art \& Design, Universiti Teknologi MARA, Shah Alam 40450 Selangor, Malaysia \\ 2 Formgiving Research Group, Faculty of Art \& Design, Universiti Teknologi MARA, Shah Alam 40450 Selangor, Malaysia \\ rahman639@uitm.edu.my, hanif@uitm.edu.my, rafeahl@uitm.edu.my, fliana@uitm.edu.my,
}

Tel of 1st Author: +6012-6666347

\begin{abstract}
This study is partly from the on-going project and discovers the essential characteristics of the traditional Malaysian Batik. The Malaysian identity should sustain and retain as part of Malaysian heritage. The modernisation of Malaysia brought about many positive changes, but it has also impacted culture predominantly Malay batik authenticity. This review will share clear insight into how this scenario provided cultural context and meaning related to the Malaysian traditional batik motif.
\end{abstract}

Keywords: Authenticity; Batik; Malaysian; Traditional

eISSN: 2398-42870 2021. The Authors. Published for AMER ABRA cE-Bs by e-International Publishing House, Ltd., UK. This is an open access article under the CC BYNC-ND license (http://creativecommons.org/licenses/by-nc-nd/4.0/). Peer-review under responsibility of AMER (Association of Malaysian Environment-Behaviour Researchers), ABRA (Association of Behavioural Researchers on Asians/Africans/Arabians) and cE-Bs (Centre for Environment-Behaviour Studies), Faculty of Architecture, Planning \& Surveying, Universiti Teknologi MARA, Malaysia.

DOI: https://doi.org/10.21834/ebpj.v6iSI5.2937

\subsection{Introduction}

Batik is a common textile technique that has spread and become well-known all over the world for its use in textiles. Traditional batik is a tradition in Malaysia that contains a great deal of symbolism and has a wide range of interpretations. This textile heritage's spirit and treasure are expressed through the one-of-a-kind designs on batik. This review focuses on the related studies that are consistent with the authenticity of Malaysian traditional batik from the previous and most recent compilations.

\subsection{Literature Review}

A recent related study aimed to detecting counterfeit batik sarongs in terms of design, including patterns, colours, and structure. Field visits, observation, and interviews are among the methods that have been employed. The situation in the batik business, as well as the characteristics that deceived customers, were described in detail in this study. It is not traditional to wear an imitation batik sarong because the traditional method and characteristics haven't been visually preserved on it. This research should be used to clarify how innovation can continue to play a role while traditional batik continues to develop without becoming suffocating (Sobri and Legino, 2020). batik items from Malaysia are among the most popular textile handicrafts in the world, and they are often purchased as souvenirs by visitors. The price, design, and location of the goods all played a role in the tourist's decision to purchase them. Based on tourist spending patterns, it appears that prices are slightly higher than usual. Additionally, it is proposed that this study investigates additional factors such as tourists' perceptions of their behaviour during the purchasing process (Pesol et al., 2016).

The other study discovers new tools or materials for producing batik using natural resources as tools. The investigation will serve as a guide for batik producers and may also be used as a teaching tool in academic institutions. They are finding lines that can be a new invention in textile design based on the investigations (Noorizan et al., 2015). The case study focuses on the community services

eISSN: 2398-4287C 2021. The Authors. Published for AMER ABRA cE-Bs by e-International Publishing House, Ltd., UK. This is an open access article under the CC BYNC-ND license (http://creativecommons.org/licenses/by-nc-nd/4.0/). Peer-review under responsibility of AMER (Association of Malaysian Environment-Behaviour Researchers), ABRA (Association of Behavioural Researchers on Asians/Africans/Arabians) and cE-Bs (Centre for Environment-Behaviour Studies), Faculty of Architecture, Planning \& Surveying, Universiti Teknologi MARA, Malaysia.

DOI: https://doi.org/10.21834/ebpj.v6iSl5.2937 
programme in Kampung Malon, Gunungpati, which is run by the city of Semarang. It focuses on the batik home business of Zie Batik cloth. Natural pigments were collected from various plant parts (stems, leaves, wood, bark, and fruit) of diverse species for this type of material. These pigments are more biodegradable, somewhat safe, and easy to obtain than synthetic colours, with no liquid waste (Martuti et al., 2020).

On the hand, the Indonesian identity in developing the current philosophical ideas of batik, the possibilities of using batik to express key regional identities, and the role of identity in design development strategy. The historical regional identity, local wisdom essence, acculturation, different hues, and original batik patterns were discovered (Syabana \& Park, 2020). In the 1970s, the advent of imitation batik, often known as batik-patterned textile, destroyed many traditional batik enterprises. Many regular consumers have become victims of fake batik, believing they had acquired the genuine article. The centre for crafts and batik's research and development to determine the authenticity of Batik and its imitation (Salma \& Eskak, 2020). The usage of batik as a design culture legacy in Kampong Laweyan, a hamlet in the Surakarta (Solo) province of Java, Indonesia. This study aims to learn how batik, from its original home, aided the emergence of a tiny town out of economic downturns while dealing with the effects of globalisation. However, the supportive mechanisms and efforts at the local and national levels raise awareness and interest in traditional batik heritage (Poon, 2020). The diversity of civilisations across the world is manifested in a variety of ways, including clothing. Costumes have deep meaning and are crucial visual markers through which society displays its identity, whether they evolved from tradition or social, cultural, political, and economic factors. We reviewed several classic African, Asian, and European clothes to grasp their similarities and differences and their symbolic importance in preserving national values and cultural heritage (Rudie, 2013). The United Nations Educational, Scientific, and Cultural Organization (UNESCO) has identified batik as a vital component of the elusive social legacy of mankind, one of the practises or living expressions carried down from our forefathers to our descendants. Without traditional batik, a country's identity and the modern world's may be lost to expose dyeing technology through an innovative technique. This study demonstrates the logic of traditional batik in producing idea design even while competing with digital batik that makes full use of high-tech techniques (Abd Nasir, 2017). Traditional textiles, particularly handwoven ones, have long been traded across the world. Textiles were regarded as valuable before they were mass-produced. The industrial revolution enabled textiles to be mass-produced quickly and at a low cost for the mass market. Throughout Southeast Asia, traditional fabrics are still utilised for lifecycle and religious events. Textiles from the past would be regarded as cultural products. A worldwide web-enabled audience interested in traditional textile end products has the potential to increase demand. Telling their experiences on the internet draws attention and authenticity to their products, which should increase sales (Crippen \& Mulready, 2014).

As the globe has become a sphere of interconnected communities, the use of artefacts as ethnic identifiers has become increasingly challenging. People in post-contact cultures (Philippines and Indonesia) modify their material culture and the ethnic identity it symbolises as they bow to the demands of other groups while adjusting their internal wants. In such instances, both external action and native complicity influence ethnic representation (Tolentino, 2012). The possibilities of developing traditional Malaysian handicrafts using social media to revitalise traditional cultural values that appear to have dwindled as a result of modernisation. Support for aesthetic, cultural values via digital media is anticipated to preserve and increase the worth of Malaysian traditional handicraft culture. Previously, the traditional sector was reliant on visitors. Instead of relying on visitor arrivals, handicraft merchants may now transport items to tourists' doorsteps in the borderless market (Hassan et al., 2020). The Indonesian Ministry of Trade implemented an import bureaucratisation policy that limited the import of 'textile and textile product' (TPT) of batik and printed batik. The economic goal is to safeguard the indigenous batik sector against the flood of imported batik into the Indonesian textile market, particularly from China. According to the researcher, the ICHS Convention has a significant potential to legitimise batik items as Indonesian products that need to be protected in any way (Sholihah 2019). The commercial hand-drawn batik apparel design and dress practice in the Klang Valley and emphasises the ideas of youth about hand-drawn batik as fashion wear and what influences them to wear batik or not. The research sample was young individuals aged 19 to 25 from undergraduate students from the University of Malaya; both genders, ethnic groups and racial composition were included (Pegah, 2017). UNNES Chemistry students were taught about chemical products in a project called "chemical batik", which involved the fabrication of chemical batik, followed by evaluation and assessment. Findings suggest that Natural Product learning linked with Ethno-STEM was influential in developing students' chemistry knowledge (Sumarni \& Yulianti, 2019). Malaysia is obligated to identify and characterise the different aspects of the Intangible Cultural Heritage (ICH) found on its territory and safeguard them. The issues to be addressed include a lack of awareness about the nature of $\mathrm{ICH}$ and restricted interpretations and scope of $\mathrm{ICH}$. Malaysia adopted the UNESCO Convention for the Protection of Intangible Cultural Heritage in 2013 (Zaky \& Azmi, 2017).

\subsection{Methodology}

The methodology is a procedure for breaking down a study into manageable phases that is followed. The research objectives are the first components to be considered in order to obtain the output. Additionally, an observation technique aids in the achievement of specific objectives that have been established and validated in this study. As the central observation of this research, we will use the example 
of batik as mapping with regard to authenticity elements, regardless of whether it is traditional process or machine printed. This also falls under the category of the forms and lines of the, which are distinctive to its designs.

\subsection{Finding and Discussion}

The originality of batik is recognized through the traditional character on the surface on the cloth. It involved with the technique, process and also the design. We understand that the term "batik" has already come to represent the expansion of a technique that has become widely accepted in society. The design motifs of batik are also a main feature that strongly a main element that interweave the batik authenticity character. The surrounding flora and fauna influence the development of the batik motif in Indonesia and Malaysia. Indeed, Kari et al., 2017 stated that batik authenticity is in how the original batik character is one of the main textiles products of Terengganu and Kelantan. The products have its own identity in facing the competitive imported batik product in the market today. In order to keep the traditional tradition alive, the batik technique of wax-resist colouring on cloth is still used in Kota Bharu and Kuala Terengganu. The finding from this project, when the discussion about the authenticity of batik, the previous study is also referring that the element of batik is on decorative fabrics containing various colours and patterns from tha batik technique (Nordin \& Abu Bakar, 2012). On the other hand, the issue of authenticity of batik is not raised in our country only, in Indonesia where the example of the study by Ramdoni et al., (2019) where Trusmi batik is a company that produces various kinds of batik, including mega mendung batik motifs. The company has problems on how to minimize artificial batik and how to distinguish original batik from imitation. Trusmi batik is based in Cirebon, which has a traditional batik center. The other example is also concerned with batik authenticity, and it examines the effectiveness of batik authenticity detection by taking into account a variety of factors that could have an impact on the performance of the application. Camera position relative to the marker, camera resolution, and browsers used to access the application's website were all factors considered in this study (Christianto, 2018). As a result, the traditional batik technique is important in the lives of everyone, not just batik producers and consumers.

\subsection{Conclusion}

To sum up, batik is a widespread technique that has expanded and been recognised in textiles worldwide. Traditional batik is a tradition in Malaysia that is rich in symbolism and significance. The one-of-a-kind designs on batik capture the spirit and value of this textile history. This study focuses on relevant research from earlier and contemporary compilations consistent with Malaysian traditional batik authenticity.

\section{Acknowledgements}

The authors would like to acknowledge the Research Management Center (RMC), Universiti Teknologi MARA, for funding under the grants of the 600-IRMI 5/3/GIP (014/2018)) for this project.

\section{References}

Abreu, R., Leite, M., Jorge, J., Grouller, F., van der Zwaag, W., leal, A., \& Figueiredo, P. \{2016). Ballistocardiogram artefact correction taking into account physiological signal preservation in simultaneous EEG-fMRI. Neuroimage.

Abd Halim, N., TS, T. I. S., \& Ramli, N. (2021). DECORATIVE ARTS OF THE BATEK INDIGENOUS PEOPLE: A SYSTEMATIC DOCUMENTATION OF FEATURES. Journal of Nusantara Studies (JONUS), 6(2), 273-295

ABD HAMID, N. F. B. (2017). THE SUSTAINABILITY OF MALAY TRADITIONAL CRAFTSMANSHIP AS A TOURISM PRODUCT IN MELAKA

Abd Manaf, Z., Ismail, A., Razlan, N. M., Abd Manaf, A., \& Daruis, R. (2013, May). Risk management for digital cultural heritage information in Malaysia. In International Conference on Information Management and Evaluation (p. 1). Academic Conferences International Limited.

Abd Nasir, N. H. B. (2017). Market rationale on traditional batik design sustainability (Doctoral dissertation, Universiti Malaysia Kelantan).

Alexander, S. A., \& Schiesser, C. H. (2017). Heteroorganic molecules and bacterial biofilms: Controlling biodeterioration of cultural heritage. ARKIVOC: Online Journal of Organic Chemistry, 2017.

Andriulo, F., Braovac, S., Kutzke, H., Giorgi, R., \& Baglloni, P. (2016). Nanotechnologies for the restoration of alum-treated archaeological wood. Applied Physics $A, 122(4), 1-9$.

Antoniazzi, L. (2020). Digital preservation and the sustainability of film heritage. Information, Communication \& Society, 1-16.

Amenta, L. C. (2014). Building a Future for the Past-The Sustainability of Digital Archiving Processes in Audio-Visual Cultural Heritage Organizations (Master's thesis).

Bagur-Femenías, L., Buil-Fabrega, M., \& Aznar, J. P. (2020). Teaching digital natives to acquire competencies for sustainable development. International Journal of Sustainability in Higher Education. 
Brennen, S., \& Kreiss, D. (2014). Digitalisation and digitisation. Culture digitally, 8.

Chaterera, F. (2013). Beyond documentation: an analytical approach towards the future of museums as information centres (Doctoral dissertation, Midlands State University).

Cheng, H. M. (2012). The workflows of 3D digitising heritage monuments. Laser scanner technology, 183.

Elsaesser, T. (2016). Media archaeology as a symptom. New Review of Film and Television Studies, 14(2), 181-215.

Carroll, A. J., \& Mallon, M. N. (2021). Using digital environments to design inclusive and sustainable communities of practice in academic libraries. The Journal of Academic Librarianship, 47(5), 1023

Crippen, K., \& Mulready, P. (2014, July). SPINNING YARNS-WEAVING TEXTILES CASE: CREATING AUTHENTIC INTERNET STORIES. In 2014 Global Marketing Conference at Singapore (pp. 1453-1458).

Christianto, P. A., Restyandito, E. B. S., \& Maulana, M. R. (2018). Factors Influencing the Performance of Batik Authenticity Detection Application.

Doulamis, A. D., Voulodimos, A., Doulamis, N. D., Soile, S., \& Lampropoulos, A. (2017, February). Transforming Intangible Folkloric Performing Arts into Tangible Choreographic Digital Objects: The Terpsichore Approach. In VISIGRAPP (5: VISAPP) (pp. 451-460).

Drucker, J. (2021). Sustainability and complexity: Knowledge and authority in the digital humanities. Digital Scholarship in the Humanities.

Fachinger, J., den Exter, M., Grambow, B., Holgerson, S., Landesmann, C., Titov, M., et al. (2004). Behavior of spent HTR fuel elements in aquatic phases of repository host rock formations, 2nd International Topical Meeting on High Temperature Reactor Technology. Beijing, China, paper \#B08.

Gupta, D. K., \& Sharma, V. (2017). Enriching and enhancing digital cultural heritage through crowd contribution. Journal of Cultural Heritage Management and Sustainable Development.

Hassan, H., Sade, A. B., Migin, M. W., \& San Khaw, O. (2020, December). Cultivating Traditional Malaysian Handicraft Market Demand through Social Media Technology. In 2020 IEEE 8th R10 Humanitarian Technology Conference (R10-HTC) (pp. 1-6). IEEE.

Hockx-Yu, H. (2006). Digital preservation in the context of institutional repositories. Program.

Ibrahim, R., Razalli, A. R., Abdullah, N., \& Marlina, S. P. CAREER TRANSITION PROGRAMME FOR STUDENT WITH LEARNING DISABILITIES: IN EXCELLENT TEACHERS OWN WORDS.

Kabanda, P. (2014). The creative wealth of nations: how the performing arts can advance development and human progress. The World Bank.

Mehdi K., \& Koorosh, A. (2015). Achievement to Environmental Components of Educational Spaces for Iranian Trainable Children with Intellectual Disability. Procedia Social and Behavioral Sciences, 201, 9-18.

Kari, R., Samin, M. A., \& Legino, R. (2017). Sustainability of the Batik Block Industry in Kelantan and Terengganu. Advanced Science Letters, 23(11), 10769-10773.

Laxmita, N. A., Setyaningsih, W., \& Purwani, O. (2021, May). Sustainable rural tourism development in the era of social media shapes identities and digital discourse settings. In IOP Conference Series: Earth and Environmental Science (Vol. 778, No. 1, p. 012010). IOP Publishing.

Lutz, S. (2017). \{D1G1TAL HER1TAGE\}. From cultural to digital heritage. Hamburger Journal FüR Kulturanthropologie (HJK), (7), 3-23

Makarova, E. A., \& Makarova, E. L. (2019). The functional model of using visualisation and digitalisation for media literacy development in the media education process. Медиаобразование, (4).

Martuti, N. K. T., Hidayah, I., Margunani, M., \& Alafima, R. B. (2020). Organic Material for Clean Production in the Batik Industry: A Case Study of Natural Batik Semarang, Indonesia. Recycling, 5(4), 28.

Mettam, G. R., \& Adams, L. B. (1999). How to prepare an electronic version of your article. In B. S. Jones \& R. Z. Smith (Eds.), Introduction to the electronic age (pp. 281-304). New York: E-Publishing Inc.

Ning, Y. Y., Hua, W. K., Ming, C. H., \& Shan, H. W. (2011). The standard of management and application of cultural heritage documentation. Geoinformatics FCE CTU, 6, 354-363.

Noorizan, M. F., Ramli, I., \& Nawawi, N. M. (2015). The Exploration Technique of Nature for Contemporary Batik Design. In International Colloquium of Art and Design Education Research (i-CADER 2014) (pp. 277-287). Springer, Singapore.

Pegah, J. (2017). Commercial hand-drawn batik apparel and its market potential with young Malaysians/Pegah Jahangiri (Doctoral dissertation, University of Malaya).

Pesol, N. F., Mustapha, N. A., Ismail, S. S., \& Yusoff, N. M. (2016). The attributes of Malaysian Batik towards tourist purchase decision. Tourism, Leisure and Global Change, 3, 105-116.

Poon, S. (2020). Symbolic Resistance: Tradition in BatikTransitionsSustain Beauty, Cultural Heritage and Status in the Era of Modernity. World, 7(2).

Ramdoni, D., Sugiharto, T., Permana, A., \& Nugraha, R. (2019). Implementation of the FAST Fast Corner Detection Algorithm (Feature Form Accelerated Segment Test) and Augmented Reality to Determine the Authenticity of Batik Case Study (Batik Trusmi) Cirebon. Balong International Journal of Design, 1(1).

Rudie, I. (2013). " Chapter 2 Ethnic Experience and Global Horizons: Batik Entrepreneurs on a Tourist Beach in Malaysia". In Embedded Entrepreneurship. Leiden, The Netherlands: Brill. Doi:

Salma, I. I. R., \& Eskak, E. (2020). Keeping the Genuine of Batik in the Age of Artificial Intelligence. Available at SSRN 3807704. 
Sholihah, S. F. (2019). Unesco's intangible cultural heritage safeguard in Indonesia's policy of Batik and printed batik 2015. In Culture and International Law (pp. 110124). CRC Press.

Sobri, A. I., \& Legino, R. (2020). Imitation of Batik Sarong Design and Features. Environment-Behaviour Proceedings Journal, 5(SI3), 99-108.

Sumarni, W., \& Yulianti, D. (2019, November). Developing Students' Entrepreneurial Characters through Downstreaming Research on Natural Products Learning with Ethnoscience Integrated Stem. In Journal of Physics: Conference Series (Vol. 1387, No. 1, p. 012085). IOP Publishing.

Syabana, Y. M. K., \& Park, G. B. (2020). A study on the applicability of Batik for public transportation design in Indonesia. Journal of Mechatronics, Electrical Power, and Vehicular Technology, 11(2), 75-85.

Testa, M. V., McNellis, R., Gibson, C. T., \& Wiesner, S. (2021). Session 10. Postmodernism in the Performing Arts Archive.

Tolentino Jr, D. (2012). Authentic/adulterated artifacts: Material culture and ethnicity in contemporary Java and lfugao. Wacana Seni Journal of Arts Discourse, 11, 3961.

Wang, D. (2018). Exploring a narrative-based framework for historical exhibits combining JanusVR with photometric stereo. Neural Computing and Applications, 29(5), 1425-1432.

Zaky, S. Z. N., \& Azmi, I. M. A. G. PROTECTION FOR INTANGIBLE CULTURAL HERITAGE AS A VIABLE TOURIST PRODUCT: MALAYSIA AS A CASE STUDY 